\title{
Antonio Paz Míguez ou o Adán que non quixo voltar
}

\author{
ESPERANZA MARIÑo DAVILA
}

\section{O HOME E A OBRA}

Contra finais do ano 1992 púxose á venda en numerosas librerías galegas un libro de curiosa factura, escrito nunha ortografía distinta a calquera das propostas coñecidas. ¿Individualismo a ultranza ou anacronismo? Sen dúbida, a explicación lóxica responde a isto último, posto que o autor en cuestión leva afincado definitivamente en Buenos Aires desde marzo de 1936, e entre tanto a lingua que manexa permaneceu, mutatis mutandis, idéntica á que utilizara alá polos anos trinta, antes da Guerra.

Certamente, Paz Míguez ${ }^{1}$ constitúe un caso moi particular nos eidos literarios galegos. Estreouse como escritor con Da Emigración ${ }^{2}$ (1936), novela que pasou practicamente desapercibida no tumultuoso contexto da época e da que se conservan hoxe en día contados exemplares a respecto da edición orixinal. Deste descoñecemento xeral constitúen testemuño veraz as equívocas, alén de escasas, noticias posteriores sobre o suceso ${ }^{3}$.

' Antonio Paz Míguez nace na Pobra do Caramiñal (A Coruña) o catro de xuño de 1911 — non de xullo, como sostiven equivocadamente no limiar da edición facsímile - e en 1929 emigra á Arxentina (Rosario, primeiro e logo, Bos Aires). Na cidade porteña mantén contactos co nacionalismo galego, que reitera na volta a Galicia en 1935; tras moitas dúbidas, emigra de novo a Bos Aires en marzo -que non maio- de 1936. Regresa á Terra natal para unha curta visita no ano 1971 e arestora, octoxenario, continúa a vivir na Arxentina.

2 A principios de 1993 o Concello da Pobra tivo a excelente idea de subvencionar unha edición facsímile precedida dun completo estudio e de carácter non venal, co fin de espallala entre os concidadáns.

${ }^{3}$ Así, tan só Couceiro Freijomil no Diccionario (1954: 49) reseña a existencia da obra, de onde tomaría máis tarde a información Carballo Calero (1977 e 1978: 65-71), presentándoa serodiamente na Historia da Literatura Galega Contemporánea (1981: 767). Aínda na Gran Enciclopedia Gallega (1974: 89-90) o confusionismo máis absoluto queda patente; Fabeiro Gómez erra, asignando unha mesma novela ora a Antón Paz Míguez ora a Antonio Paz Domínguez (inventado como tal). Outros datos erróneos barallados constitúenos a volta deste a Galicia no ano 1934 e a partida en 1939, reiterados por Teira Luaces en época recente. 
Tanto Da Emigración como $O$ Adán que non quixo voltar ô Paradiso compoñen toda a producción novelística escrita en lingua galega, se ben existen outras obras en español como Galicia. Tierra de peregrinar (1988), publicada en Bos Aires, e as aínda inéditas El restaurador de la O.C.A., El regreso a la isla e Los amigos (ambas as dúas de teatro), amén de varias poesías.

Non é casual constatar que na primitiva intención do autor figurase tamén publicar $O$ Adán... en español e na Arxentina ${ }^{4}$. Non é casual porque, na realidade, a novela desenvolve a historia dun emigrante galego de idade madura, residente en Bos Aires e cun pano de fondo abondo hostil: a profundísima crise política e social habida nas décadas dos setenta e oitenta, que dá lugar a todo tipo de disertacións para poñer fin a tal desorde, achegando diversas receitas; este e non outro é o fin didáctico perseguido.

Posto que o urdimento ideolóxico domina -con moito- seguidamente tentarase, en primeiro lugar, demostrar o paralelismo e afastamento entre as dúas obras, a máis antiga e a recente, e a continuación farase un estudio pormenorizado da última.

Se en Da Emigración o nacionalismo se amosa de xorne visceral, en $O$ Adán que non quixo voltar ô Paradiso a galeguidade cínxese en exclusiva a un feixe de tópicos, tales como unha lene morriña, desconfianza, individualismo e fortaleza anímica — desenvolvida esta tanto por mulleres como por homes-.

Se na obra de 1936 a historia, lingua e literatura presupoñen os piares constitutivos da identidade dun pobo, posteriormente desbótase a lingua como obstaculizadora dunha pretendida fraternidade peninsular; a literatura galega, considerada nun principio só a escrita nesta lingua, pasa despois a mesturarse coa escrita en español por galegos. Así, figuran lado a lado Rosalía e Valle Inclán, Curros e Fernández Flórez. A historia de Galicia, primeiro descoñecida pero reivindicada, pasa a diluírse no contexto "nacional", rendendo pleitesía de xeito flagrante a periferia ao centralismo.

Pero a mudanza máis notable ocorre nas concepcións relixiosa e política. Aínda coa apoiatura dun forte substrato católico, os inútiles rezos destacan primitivamente, para logo postularse a ultranza unha concepción teolóxica da vida e considerar como nefando todo desviacionismo. Do mesmo xeito, en política rexeitábanse antano por igual comunistas e monárquicos "cavernícolas", defendéndose a República, o Socialismo e o Galeguismo:

trataremos de chegar â nivelación xeneral e universal por medios progresivos. Destruiremos os grandes latifundios, que ô final veñen a ser como un remedo da propiedá íntegra do Estado que mata as aspiracións de libertá e independencia coleutiva, facendo d'esa maneira a esclavitú e non a liberalidá dos individuos. A Repúbrica Hespañola (...) É unha

\footnotetext{
${ }^{4}$ Segundo explicita na carta a un irmán, datada en febreiro de 1990 e na actualidade tamén no meu poder.
} 
Repúbrica de traballadores, quer decir, que reconoce a todol-os ciudadanos como traballadores, non importa que sexan obreiros materiaes, intelectuaes ou centificos, pois tod'o que redunda en be-neficio da humanidá e do progreso, debe considerarse traballo. (Paz Míguez 1993: 90)

Fundarei unha sociedá das xuventudes para que se formen verdadeiros paladíns dos ideaes galegos e leven cruzadas e misións de galeguismo pol-as montañas, pol-as aldeas, pol-os pobos, pol-as cibdás. (...) Non me cansarei de gritarlles a todos de que ante todo debemos fortalecer o noso espíritu na forza da galeguidá, pois a endemia que padece Galicia é máis ben espiritual que corporal. Despois xa virán as renovacións esternas, (...) un pobo forte e unido que cumple os seus deberes e reclama os xustos e verdadeiros dereitos. (Ibid.: 101-102).

E hogano avógase a prol do vello Imperio perdido, co esquecemento dunha Galicia edulcorada e diluída na "gloriosa" España...

Da Emigración (1936)

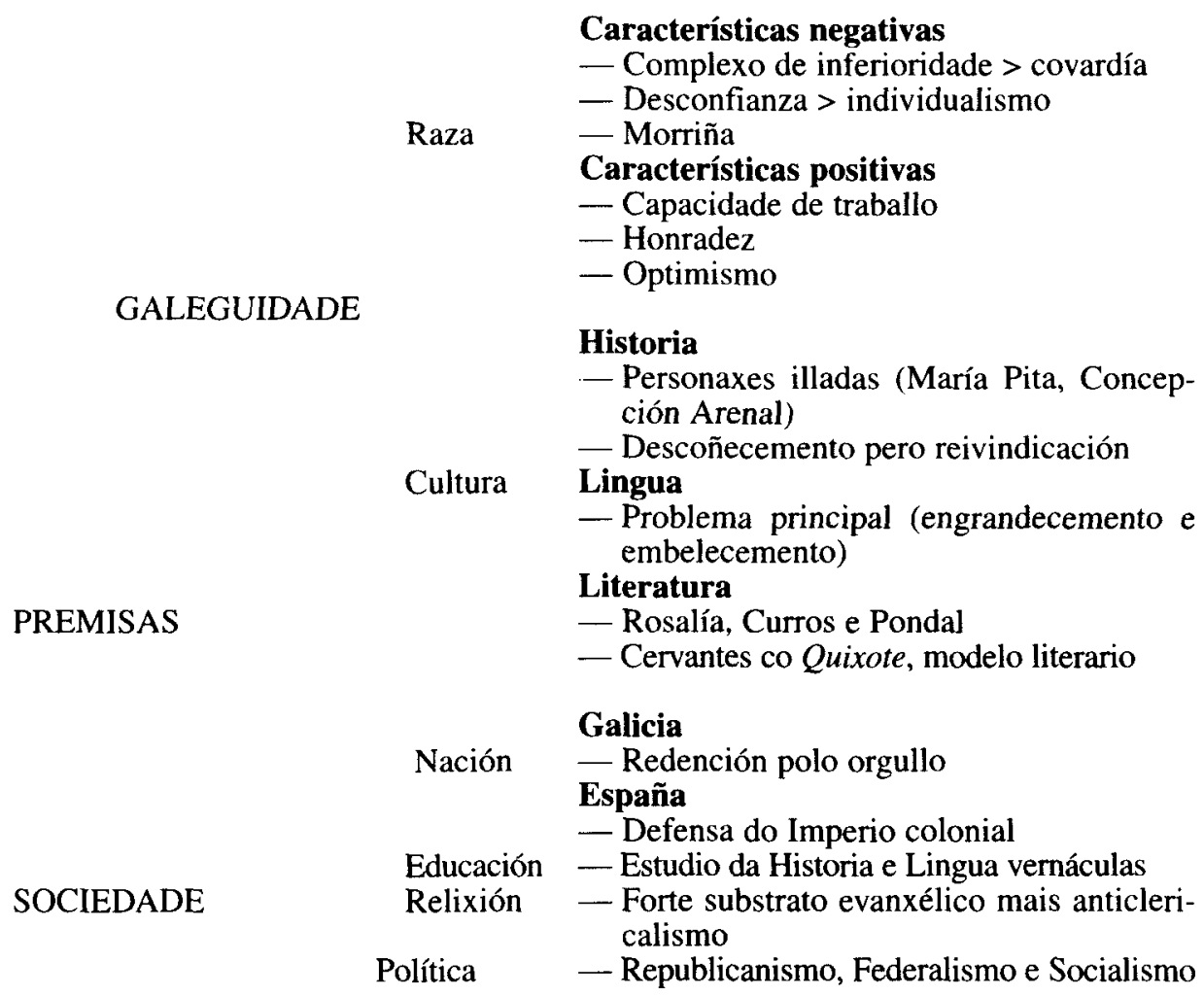


O Adán que non quixo voltar ô Paradiso (1992)

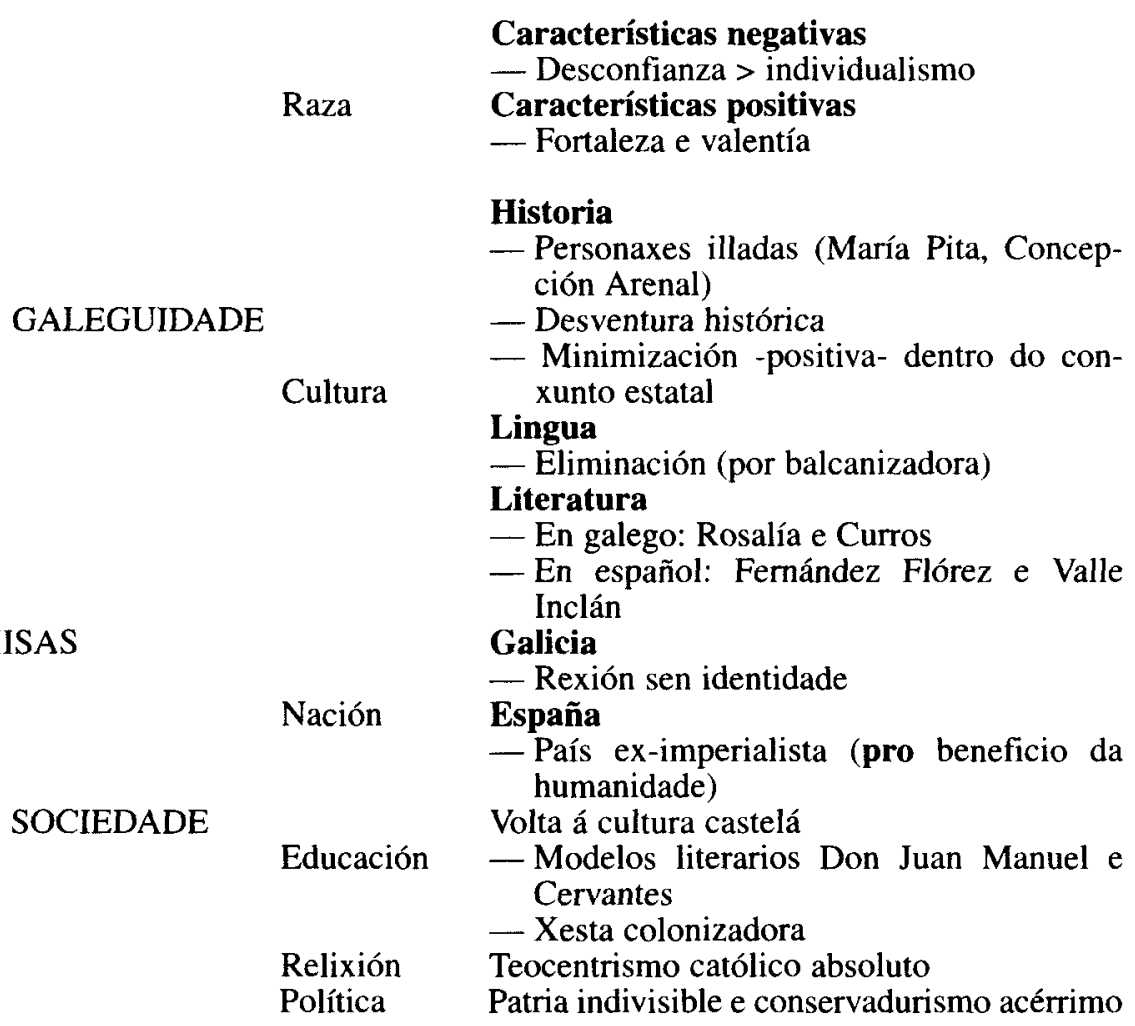

\section{CADRO SINÓPTICO DA EVOLUCIÓN IDEOLÓXICA (II)}

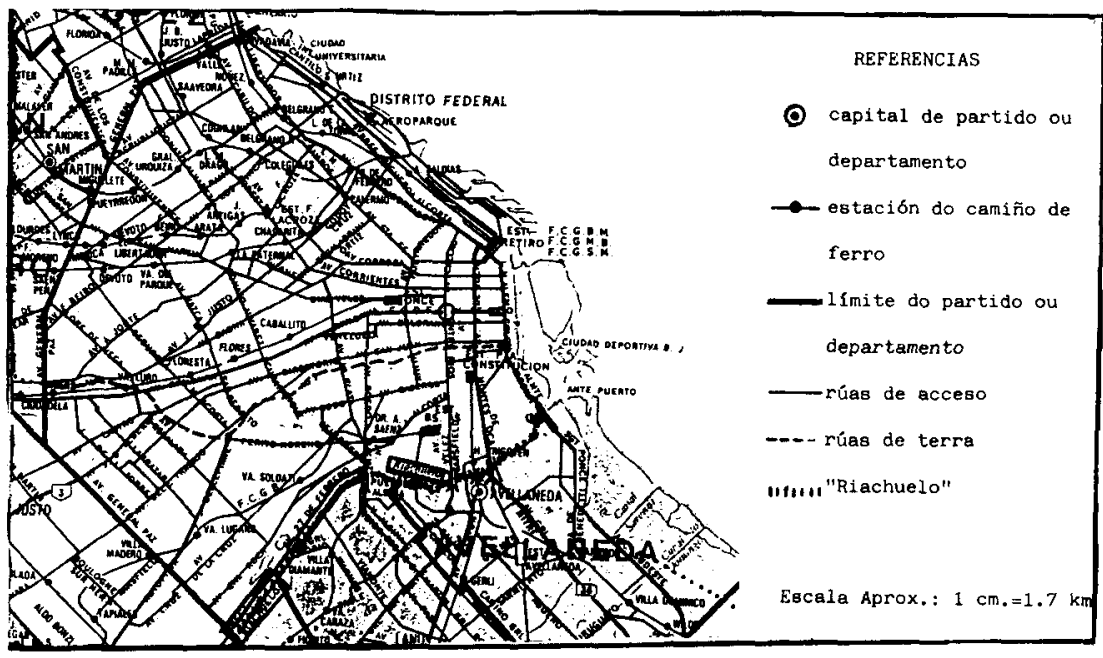




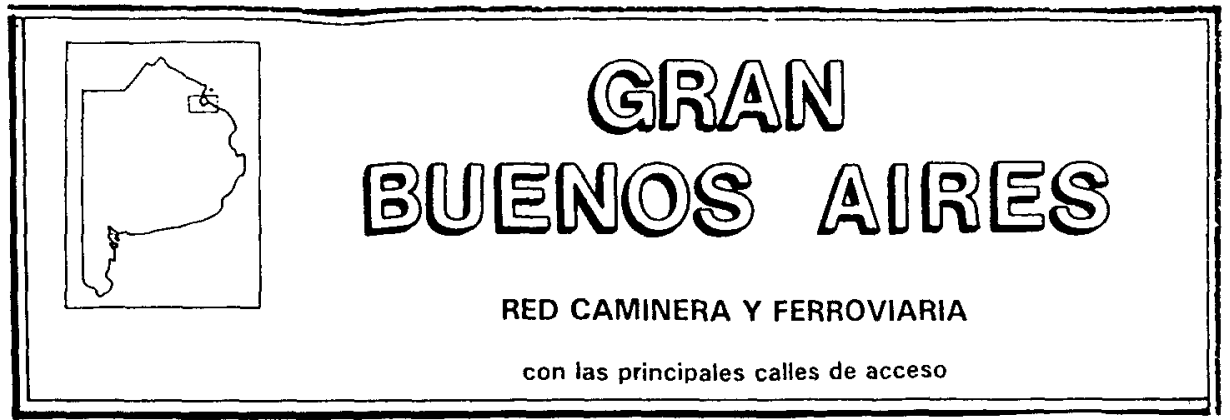

Nun principio, Antonio Paz Míguez intitulou a novela Proceso al Riachuelo, logo transformada en El fabricante de juguetes. Tras varios intentos e, debido á imposibilidade de a publicar na Arxentina, deuna a coñecer en Galicia como $O$ Adán que non quixo voltar ô Paradiso. Probablemente o primeiro título fose o máis indicado, posto que o "Riachuelo"se constitúe no verdadeiro símbolo do país, a medio camiño entre a atracción e o rexeitamento da escura realidade. (Paz Míguez 1992: 299-300)

\section{O ADÁN QUE NON QUIXO VOLTAR Ô PARADISO}

\section{PREMISAS IDEOLÓXICAS}

\subsection{Desgaleguización}

Protagonista indiscutible - metaforicamente, o Adán-, Xosé Luís (de quen xamais se cita o apelido, por inútil) constitúe o soporte substentador da obra, aínda que a función deste personaxe se basee simplemente niso ${ }^{5}$, pois o que realmente interesa é dar renda solta a un posible programa de reconstrucción nacional, sentando as bases para o mesmo.

Xosé Luís, emigrante en Buenos Aires, casado con Laura e pai de tres fillos (Roberto, Fernando e Rosiña), ve pasar os anos nun réxime desprezable, o que propicia con frecuencia a súa reflexión. As descricións da cidade porteña ubican a acción da novela; por outra banda, as referencias temporais son mínimas -explicitamente só figura o ano 1982-. O paso do tempo intúese polas medras dos fillos, desde a infancia ata ben entrada a xuventude.

Portavoz ideolóxico do autor, o galego presenta unha concepción da vida e da sociedade ben clariña. Co fin de evitar o predominio excesivo da narración,

\footnotetext{
${ }^{s}$ Outro tanto fixera Pablo en Da Emigración.
} 
de vez en cando bótase man dos diálogos para axilizar o discurso; aínda así, a miúdo o estilo resulta lento e monótono ${ }^{6}$.

\subsubsection{Galicia, España e Arxentina}

O emigrante lembra esporadicamente a infancia pasada na Pobra, paraíso perdido enclavado nas Rías Baixas e perfumado co recendo dos piñeiros bravos, fieitos, toxos,... así como da marusía:

a sua pequena vila de pescadores, co as suas calexiñas empedradas, as pequenas casas enladas cos seus tellados bermellos, o apacibre e aprisoado mar surcadopol 'as dornas, as gamelas, as lanchas, os botes e as traineras, a moitedume deillas coma querendo atracar na terra firme, as verdes e sempre húmedas campiñas, a lexendaria serra do Barban$z a$, a sua antega casa de pedra, os aserradeiros e as fábricas de conservas de pescado do Areal, o angosto e antergo peirao (...).

(Paz Míguez 1992: 69)

Mesmo se rememora a visión de Valle Inclán paseando pola vila acompañado de atentos contertulios. Non obstante, a morriña queda circunscrita a un impreciso sentimento de dó a causa da desventura histórica sufrida pola terra natal, así como á admiración da beleza que a rodea; vaguidades... pero nada profundo.

A respecto do conflicto lingüístico, en 1936 argumentábase en favor do perfeccionamento e defensa da lingua vernácula ${ }^{7}$. Asombra comprobar cómo máis de medio século despois, paradoxalmente, Galicia xa non conta, difuminada no mosaico dunha España convertida en

Patria, con maiúscula, íntegra e total e non retaceada nin subdividida ou balcanizada por antoxadizas ideoloxías nin fronteiras idiomáticas, xeográficas, económicas, ou de calquer natureza.

(Paz Míguez 1992: 280).

Como literatura galega considérase toda a escrita por galegos, independentemente do idioma; así mesmo, a historia, feita por grandes personaxes e

\footnotetext{
${ }^{6}$ Xuízo este que corroboran algúns críticos: "Trátase dunha novela de pesada lectura e excesivamente extensa na que, (...) se nos dá conta con todo detalle de diversos aspectos e problemas da nación Arxentina (...) ten un valor testemuñal e poucos méritos literarios, (...) pouco máis que unha escusa para darlles saída ás opinións e os puntos de vista do autor". (VV. AA. 1995: 435)

${ }^{7}$ Deste xeito, "o problema da fala é para min, o mais grande problema de Galicia. (...) a nosa fala, ben merece a pena traballar por ela, sacrificarse e facela tan brilante, $\tan$ suave, $\tan$ forte, $\tan$ humanamente espresiva como é nos beizos de Rosalía e Curros (...) Ese é un deber que nos corresponde a todol'os galegos, sin distincións de ningunha especie." (PAZ Míguez 1993: 51-52)
} 
nunca colectivamente, descoñece calquera raíz conformadora dunha identidade particular.

Perdida toda identidade nacional, Galicia deriva sinxelamente nunha das múltiples rexións de España; máis aínda, todo diferencialismo supón un grave obstáculo na tarefa da re-creación dunha nación forte e respectada —propugnándose de facto o traslado temporal das xentes aos diversos territorios, para a convivencia e coñecemento mutuos- - O trabucamento na indistinción dos termos "nación"8 e "Estado" non é alleo a esta concepción ideolóxica; de todos os xeitos, o autor prefire o sacrificio das pequenas nacionalidades históricas en favor dunha macroestructura poderosa que dea lugar, coma en antigo tempo, a un temido Imperio:

asi coma fomos capaces de descobrir e conquerir para beneficio da humanidá un novo e maravilloso mundo, moi bo e xusto sería que agora q'estamos liberados, d'ese tremendo compromiso histórico que tanto door e sangue nos costou, xuntásemos e debrocásemos as nosas renovadas enerxías e o noso raigal inxenio, na gran epopeia de construir e reconstruir o gran país, a gran nación que foi e que debe volver a ser España, (...).

Nesa reconstrucción dunha benaventurada Patria indivisible, terra dos ancestros e fogar da fraternidade nun senso cristián, convén non perder de vista os moldes históricos xulgados "gloriosos"9. Así, o patriotismo encárnano catro heroes representantes da loita contra toda agresión foránea: Agustina de Aragón, o Empecinado, Daoíz e Velarde ${ }^{10}$.

O abandeiramento da España victoriosa non admite fisuras... nin réplicas, acusándose de hispanofóbica toda opinión avesa, de aí que mesmo a intelectualidade máis relevante se poña en solfa ${ }^{11}$ e ata o pequeno sector disidente da clerecía $^{12}$.

${ }^{8}$ Enténdese por nación a comunidade formada por persoas de orixe común con lingua, cultura e historia propias, máis un territorio e economía colectivos mentres que o Estado vén a ser un corpo político composto por unha ou varias nacións históricas, federadas ou unidas á forza.

${ }^{9} \mathrm{O}$ berce do Estado actual asenta os piares alá polo século XV, onde os Reis Católicos Isabel e Fernando deran en xestar o Imperio, axudados polos conquistadores.

${ }^{10}$ Agustina de Aragón (1790-1858) foi a defensora de Zaragoza contra os franceses. O Empecinado (1775-1825), labrador castelán, encargouse de organizar a primeira guerrilla a grande escala. DAOIZ (1767-1808) e VELARDE (1779-1808), militares, morreron en Madrid o Dous de Maio tamén na Guerra da Independencia.

"De entre a pleiade dos escritores (LARRA, GANIVET, VALlE INCLÁN) soamente se desculpa a Unamuno pola profundísima dor, malia que encirrase o Estado.

${ }^{12}$ Representado por frei Bartolomé de las Casas (1474-1566), nomeado "protector dos indios" en 1516. O eclesiástico acúsase de extremista e desorbitado pola denuncia dos horribles abusos perpetrados contra os indíxenas, aos que algúns españois da época tiveran a ben non considerar dignos de pertenceren ao xénero humano. 
Nesta liña vólvese a mirada cara á España contemporánea baixo a Dictadura do xeneral Franco, gabándose a política do momento e arremetendo con saña contra o imperialismo ianqui e británico ${ }^{13}$.

En fin, para o programa de reconstrucción "nacional" propóñense como libros de cabeceira para todos e lectura obrigada nas escolas o Quixote e os Apólogos e Exemplos do Conde Lucanor ${ }^{14}$; a restauración dos valores da vella fidalguía compendia con orgullo un pasado ditoso, fito na historia da humanidade:

nosa groriosa historia que nos identifica como pobo e nación, considerando tamén que somos, nada máis, pero nada menos que os que viñemos a civilizar e a conformar esta criolla ou mestiza Indoiberia, Iberoamérica, Latinoamérica ou sinxelamente a Hispanidá.

(Paz Míguez 1992: 286)

Se os estragos do tempo propician que a lonxana Galicia, fantasma dun vello pasado, deixe lugar ao presente no refuxio do emigrante en Bos Aires, ese refuxio, cálido noutrora, vese alterado pola caótica situación nacional da época, en particular o setenio $1976-1983^{15}$. Caos reflectido na Dictadura militar, a Guerra das Malvinas, as manifestacións silenciosas das Nais da Praza de Maio cada xoves, a débeda externa, a inflación, o despido libre, os recortes nas prestacións sociais...

Sicasí, o ano 1983 transcorre nunha grande efervescencia política ante a inminente caída da Dictadura, recreada por medio dun diálogo entre Roberto, o fillo primoxénito estudiante de Enxeñería e Xosé Luís, que debaten os problemas e posibles solucións do desastre arxentino. Roberto encarna o desencanto, maioritario entre os xoves, partidario do abandono da patria o antes posible, fronte á ardente defensa por parte do pai. Tal diálogo resulta interesante porque complementa a crítica situación presente, manifestando a desorde hospitalaria e a carencia de escrúpulos de moitos galenos, os mortos ignominiosamente pola Dictadura e a corrupción xeneralizada:

Dixéronme que foron sacados de noite das suas casas e ninguén sabe decir en donde están nin de qué están acusados, porque nin autuan os xueces nin hai maneira de que seian defendidos legalmente polos abogados defensores. Oise decir que están enchendo os cimiterios cos corpos de xentes mozas, homes e mulleres, que ninguén sabe decir de quén

${ }^{13}$ O primeiro, por vetar a entrada de España na ONU — boicot roto unicamente pola "nobre" República Arxentina- e o segundo, pola usurpación de Xibraltar.

${ }_{14}^{14}$ Dos grandes próceres Cervantes (1547-1616) e Don Juan Manuel (1282-1348).

${ }^{15}$ En marzo de 1976 un golpe militar derroca á Presidenta María Estela Perón e instaura unha Xunta militar gobernada polos xenerais Videla, LIENDO E GALTIERI; baixo o mandato deste prodúcese a Guerra das Malvinas (2-4-1982), resolta en a penas dous meses e medio de campaña. Finalmente, o tamén xeneral Bignone decide anunciar eleccións democráticas. 
se trata. (..) as augas dos ríos baixan toldas con corpos de fusilados de moi dificil ou imposibre identificación, porque están mutilados de tal maneira que non se pode saber de quen se trata. (...) Acordate do tango Cambalache. Pior que Cambalache é xa este país. 'Este noso país! 'Que non lle van a deixar nada sin roer!' 'Nin os osos siquera, como se ve nos campos nas épocas de sequía! Porque está caido (...)

(Paz Míguez 1992: 403, 413)

Xosé Luís, como home maduro e experimentado, acode en defensa da arxentinidade perante a familia, confiando na moita riqueza aínda sen explotar e propoñendo medidas para paliar o $\operatorname{cas}^{16}$. Así mesmo, incide na elevación da autoestima co relembro da brillantez intelectual, tanto no terreo científico como no humanista ${ }^{17}$.

Galicia, no pasado, non supón máis que unha bela e morriñenta lembranza; a Arxentina, no presente, é a esperanza, o futuro, todo, mesmo na adversidade.

En resumidas contas, o amor pola terra adoptiva é tan inmenso que un emigrante de orixe vasca, Ignacio Belaúnde, non pode menos que subliñar o acrioulamento e inmersión no irresistible encanto da cidade:

-Amigo Xosé Luís, permiteme que che diga que por máis que queiras disimulalo, xa te sintes máis porteño ou criollo q'español; porque non fai falta ser un lince para darse conta de que estás enamorado de Buenos Aires hastr'a o miolo dos osos. (Paz Míguez 1992: 301)

\subsection{Sistema tRADICIONALISTA}

O conservadurismo en todas as ordes vislúmbrase a través das páxinas de $O$ Adán que non quixo voltar ô Paradiso, por exemplo, na profunda crítica a calquera das manifestacións da Arte contemporánea (o que conleva a catalogar como artistas aos "de antes": Velázquez, Murillo, Rafael, Miguel Anxo; entre os novos, só Dalí se zafa da desfeita). Crítica posta en boca dun camareiro con inquietudes intelectuais para así resultar menos directa:

vexa vostede o que está pasando co teatro e co cine. Puros bodrios. $\tilde{n} E$ co a pintura? Mamarrachos. Pintura abstrata. Non figurativa. Adefesios. Esperpentos.

${ }^{16}$ As medidas son, no ámbito social, o rexeitamento do individualismo e a homoxeneidade; no gubernamental, o exemplo de políticos patrióticos (tales como Alvear) e no económico, o saneamento por medio da creación de empresas a través de créditos bancarios.

${ }^{17}$ E de aí os nomes de B. A. Houssay (1887-1971) e L. F. LeLorR (1906-1987), Premios Nóbel en Medicina e Química, respectivamente e mais os dos afamados escritores J. L. BoRGEs (1899-1986) e M. Mujica Laínez (1910-1984), por exemplo. 
Verdadeiros enxendros da cousa máis grotesca que se pode imaxinar. Si o estamos vendo. E o paradóxico e o cómico do caso é, que ninguén se atreve a decilo, coma pasaba con aquel lexendario rei que andaba nudo pol'as rúas.

(Paz Míguez 1992: 116)

De igual forma, o turismo é xulgado con certo receo por inmoral, posto que contribúe ao desleixamento nos costumes; o amor libre, ídem. A orde e lei establecidas vense ameazadas por elementos coma os hippis e afíns, inimigos da limpeza, preguiceiros, enlouquecidos coa súa música barullenta e sádica e atordoados pola droga... Liberdade pero non libertinaxe, isto é, un sistema virado de costas á xuventude rebelde, coa vista fixada nos devanceiros e baseado en palabras como familia, patria, honor, virtude, etc.

\subsubsection{Relixiosidade}

O título mesmo da obra resulta aclaratorio por canto supón moito máis que unha metáfora embelecedora; unha concepción profundamente teocéntrica subxace na exaltación dun Deus omnipotente creador do Universo, tirando validez a calquera hipótese científica contraria. $\mathrm{Na}$ contenda ciencia - relixión, a fe prima:

negan a eisistencia dun pai común, dun Facedor ou Creador ô que chamamos Deus, Alá ou Xavé ou Xeová. Son os chamados ateos, ou os que preferen ser descendentes dos gorilas ou dos orangutáns ou de calquera especie de simios máis ou menos darwinianos.

(Paz Míguez 1992: 263)

Sentado tal principio, esgrímese unha concepción relixiosa baseada na relixión católica, apostólica e romana máis ortodoxa que, con leis firmemente explicitadas nos mandamentos divinos, dea lugar á verdadeira fraternidade cristiá que os ateos ou impíos están abocados a descoñecer. A figura de Cristo, como redentor do destino da humanidade, constitúe o punto de referencia: realmente, trátase de perpetuar a civilización occidental de feitío cristián fronte ao neopaganismo científico ou filosófico.

Posto que toda práctica relixiosa necesita duns representantes -intermediarios entre a divindade e os mortais-, duns templos e duns ritos, proponse a oración humilde antes ou despois das comidas como un magnífico costume digno de ser restablecido, así como un cristianismo ennobrecedor do ser humano, que o dignifique ao categorizalo como fillo de Deus nin superior nin inferior aos semellantes, senón irmán.

Imaxes profundamente líricas coma o rumor dos piñeiros baixando en procesión desde os cumes ata as ermidas campestres de Galicia e comentarios como o rexurdimento de España tras a Guerra Civil, asemellado ao da Ave Fénix e atribuído á confianza en Deus, completan a visión dun autor visceralmente católico, mais non en exceso tolerante nin co ateísmo nin tan sequera coas restantes confesións. 
En efecto, a existencia de moitas relixións e sectas considérase nefanda por crear barreiras á unión dos individuos, á parte de sementar confusionismo; en resumo, existe unha única relixión verdadeira e as outras foron importadas por xente de non precisamente moi boa vontade.

\subsubsection{Política}

Tomando como punto de partida frases ou ditos célebres - tanto de personaxes literarios como dos respectivos autores- pode concibirse a xénese da novela; ao igual que un redivivo Quixote, amante fidelísimo de toda xustiza, preténdese emendar o entorto político arxentino, incomprensible racionalmente a non ser polas malas artes dos politicastros ${ }^{18}$.

As solucións propostas para a cuestión arxentina pasan pola elección duns políticos acordes á difícil etapa; explicitamente, prexulgados como modélicos figuran Yrigoyen ${ }^{19}$ e Alvear, mais pode deducirse algunha admiración por un terceiro, continuador de ambos: Perón. Non podían faltar tampouco toda sorte de intelectuais, tales como Hernández e Martínez Estrada ${ }^{20}$.

Ideas políticas de menor peso constitúenas o saneamento da cidade porteña, a defensa da natalidade, o federalismo e, especialmente, a omisión de toda crítica (negativa sempre):

¿Este país! ou 'Este país de merda! Frase que se escoita nas rúas, nos teatros, nos cines, e tamén na televisión cando pasan pola TV esos filmes chabacanos donde se pretende mostrarlle ô mundo a chamada realidá arxentina, (...) todo esto está orquestado polas apátridas, polos vendepatrias e por toda esta caterva de chalratáns que queren convertir a este país en unha especie de Biafra, de Uganda ou de Libano ou cousa así, para que non quede pedra sobre pedra, (...).

(Paz Míguez 1992: 417)

Os sólidos alicerces dunha nación rexenerada teñen necesariamente que dar lugar ao milagre económico apoiado nunha anhelada confederación latinoamericana, ou sexa, tras a esperanza agromará sen dúbida un futuro feliz.

\footnotetext{
${ }^{18}$ En efecto, a Arxentina simbolizou sempre a fartura por abundar tanto en gandería como en agricultura e pesca, amais de en enormes riquezas acuíferas, minerais e petrolíferas. A terra dos enormes contrastes e variados climas, escasamente habitada en relación proporcional ao territorio, viuse pexada por unha tremenda débeda externa con países nin a metade de fructíferos.

${ }^{19}$ Hipólito YRIGOYEN (1852-1933), Presidente da nación nos períodos 1916-1922 e 1928-1930, impulsou notables reformas sociais e universitarias, á vez que mantivo a neutralidade durante a Primeira Guerra Mundial. Torcuato De Alvear (1868-1942) ocupou a Presidencia no intervalo 19221928. O dictador JuAN DOMINGO PERÓN (1895-1974) é gabado sobre todo pola política migratoria centrada na absorción de europeos, especializados en metodoloxías fomentadoras de riqueza.

${ }^{20}$ JOSÉ HERNÁNDEZ (1834-1886) é o poeta nacional arxentino por ter escrito o Martín Fierro, centrado na figura do gaucho. EzEQuiel MARTínez EsTRADA (1895-1964), importante ensaísta, destacou tamén como poeta do modernismo arxentino.
} 
Deixando de lado o problema arxentino — razón de ser da obra-, aínda quedan moitos cabos por atar despois de situala no contexto histórico en que foi escrita: a política de bloques, a ameaza universal perante unha incerta hecatombe nuclear, os cambios climáticos,...

O autor simplifica excesivamente a cuestión achacando todos os males a un e outro bloque, pero confiando á vez na lóxica dos gobernantes dos USA e URSS por amor á propia supervivencia. Non obstante, o reparto dos improperios non resulta equitativo para ambas as dúas partes, pois os Estados Unidos, aínda baixo a acusación da tendencia a un desmedido imperialismo ${ }^{21}$, saen victoriosos e convertidos no bastión da liberdade e democracia.

Non ocorre $o$ mesmo co bloque comunista (metaforicamente, o Anticristo), reo de todos os males, en primeiro lugar, por se declarar inimigo da relixión deificando, paradoxicamente, o Estado pero tamén por constituírse nun réxime carcerario e abafador de nacións antes libres.

O capítulo XIII do libro, dialogado entre Xosé Luís e o amigo Belaúnde, pon de relevo o odio perante os "pescadores en río revolto" 22 . Non é de estrañar, pois, que Stalin se compare con Hitler - considerándose ambos os dous asasinos - ou que os comunistas (ou afíns) se cualifiquen de materialistas cobizosos, coma no "experimento" da Guerra Civil española:

o ouro que se levaron e que nunca devolveron nin van a devolver, por máis que sigan finxindo desprecio polo dourado metal e por canto pertenecera â odiada "burguesía", con ser cousa tan valiosa e tan lamentabre a sua perda, nunca será tan valiosa e lamentabre coma a perda d'ese millón de vidas que foron sacrificadas non por desinio de Dios, sinón por obra da premeditación e alevosía dos que tiran a pedra e agachan a man, e finxen ser amigos (...).

(Paz Míguez 1992: 265-266)

As reflexións dun emigrante poñen punto final a unha moi particular ideoloxía; a sensación primitiva de estrañeza en todas as partes - coa crítica engadida aos gobernantes españois por se desentenderen da sorte corrida pola emigración - dá lugar co paso do tempo a unha visión completamente optimista do país de acollida.

A verdadeira razón migratoria, a económica, queda diluída nunha postura idealista: o sacrificio de mulleres e homes en loita pola construcción dun mundo mellor para os descendentes.

Sicasí, o protagonista quere afincarse en Galicia, nun principio, pero a posteriori renuncia para que os fillos non herden o desarraigo do solo natal por el expe-

\footnotetext{
${ }^{21}$ Incluída a ONU, como cabeza visible.

${ }^{22}$ Culpables de acusacións tales como a división de España en faccións ata dar lugar á conflagración de 1936, `a introducción da droga en Norteamérica! e o emporcamento da xuventude aproveitando o idealismo propio desa etapa.
} 
rimentado; logo, desexa voltar temporalmente para lles presentar a nora e os netos aos avós paternos. Mortos estes, finalmente renuncia ata a viaxar... ñpor medo á intensidade das emocións? A verdade é que o amor pola Arxentina supera todo obstáculo; o Adán, impenitente, négase moi conscientemente a voltar ao Paraíso.

\section{A MODO DE CONCLUSIÓN}

En contra da maioritaria opinión dos coetáneos emigrados, xa desde época ben temperá Paz Míguez decántase por unha postura pouco real a respecto da emigración: o devezo por fuxir do cotián e vulgar.

Mas su éxodo es casi necesario, y aunque no siempre ello se ve obligado (...) sueña, y tiene aspiraciones de grandeza y la realización de sus sueños tan sólo la ve allende los mares, y por eso emigra ${ }^{23}$.

Sen embargo, nas novelas estudiadas o prisma cambia. Na primeira, $D a$ Emigración, o panorama amósase desalentador; aínda triunfando economicamente, ninguén pode resarcirse do dano moral. En $O$ Adán... o sacrificio está parcialmente sublimado por un futuro máis próspero. Con todo, a percepción das penalidades migratorias é obvia, confesando

non haber tido maior envexa, que a que sinteu e sinte polos galegos que nin quixeron nin sentiron necesidá de correr as aventuras dos emigrantes, que cousa boa non é, nin tan siquera para aqueles poucos que lograran ser favorecidos pola antoxadiza e ventoleira deidá chamada Fortuna.

(Paz Míguez 1992: 12)

En resumo, a emigración, "leva" forzosa nunha terra depauperada, é a todas as luces negativa ${ }^{24}$ para a nación de orixe (descalabros psicolóxicos á parte), de aí que se conclúa este artigo coa opinión dalguén, emigrante no seu día, que modificou tamén o xuízo primitivo a teor da experiencia:

A xeito de S.O.S.

falo na madrugada:

Pechai tódalas portas

e que xa ninguén saia.

${ }^{23}$ Así o plasma na revista porteña Céltiga (25-4-1930), vid. NúÑEz SeIXAS (1992: 64).

${ }^{24}$ Por máis que se argumente o feito de ser "cada día un pouco máis galego" (PAZ Miguez 1992: 12), semella unha tópica captatio benevolentiae. $O$ aserto demostrouse falso, por exemplo, na negativa consciente a voltar. Rexeitamento que PORTELA YÁÑEZ malinterpreta atribuíndollelo aos naturais receos, igual que se trabuca ao tomar a lingua do autor como prototipo da dos emigrantes, pois a Normativa de PAZ Míguez constitúe un caso insólito, por anacrónico (ibid.: 8). 
(Celso Emilio Ferreiro 1970: 34)

\section{BIBLIOGRAFÍA}

Carballo Calero, Ricardo; "Da Emigración", en La Voz de Galicia (16-7-1977: 3) e (8-9- 1977: 3).

- "Da Emigración", en Libros e autores galegos. Século XX, Fundación Pedro Barrié de la Maza, A Coruña, 1977.

- Prosa galega, 2, Editorial Galaxia, Vigo, 1978.

- Historia da Literatura Galega Contemporánea, Editorial Galaxia, Vigo, 1981.

Couceiro Freijomil, Antonio; “Paz Míguez, A.”, en Diccionario Bio-bibliográfico de escritores, III, Bibliófilos Gallegos, Santiago de Compostela, 1954.

FABeiro Gómez, Manuel; “Antón Paz Míguez" e “Antonio Paz Domínguez”, en Gran Enciclopedia Gallega, 24, Silverio Cañada Editor, Gijón, 1974.

Ferreiro Miguez, Celso Emilio; Viaxe ao país dos ananos, Editorial Saturno, Barcelona, 1970.

NúÑeZ SeIXAs, Xosé M.; O galeguismo en América (1879-1936), Ediciós do Castro, Sada, 1992.

Paz Míguez, Antonio; Da Emigración (Notas d'un galego), Editorial Nós, Santiago de Compostela, 1936.

- O Adán que non quixo voltar ô Paradiso, Ediciós do Castro, Sada, 1992.

- Da Emigración (Notas d'un galego), Concello da Pobra do Caramiñal, 1993.

Teira Luaces, Manuel; "Antonio Paz Míguez, un literato pobrense que vive lonxe da súa terra e esquecido", en La Voz de Galicia (5-6-1988).

VV. AA.; Diccionario da Literatura Galega, I, Editorial Galaxia, Vigo, 1995. 